\title{
Biodiversity Conservation and Diversification by Creation of Urban Micro- Environment: A Case Study of Delhi
}

\author{
Tahir $\mathbf{M}^{*}$ \\ Department of Geography, Jamia Millia Islamia, India \\ *Corresponding author: Mary Tahir, Department of Geography, Jamia Millia Islamia, \\ India, Tel: 9953560918; Email: tessytahir@gmail.com
}

\section{Research Article \\ Volume 1 Issue 1}

Received Date: September 09, 2018

Published Date: September 21, 2018

\begin{abstract}
The natural landscape has been wiped out in most part of the earth except for those areas which is either very inaccessible to mankind or is of not much use to him as of now. Material goods have always enticed man over the ages and still do, but a new morn has unsettled mankind on the realization of resources being better for mankind in their natural state than when it is used indiscriminately for various purposes. But this realization has dawned when we have already polluted all spheres and its repercussions have taken a heavy toll too.

An attempt has been made to recreate a natural landscape for living in an urban area (New Delhi) which is highly polluted being the capital city and vying with world class cities in providing immaculate infrastructure and amenities. Delhi has changed over the years in terms of weather and climate and its green belts and is now burdened with providing fresh air and water to its teeming inhabitants.

This study encompasses the problems of living in small/high rises with terrace above and the heat and cold beating down with change of seasons. This study tries to understand environment and how man can create an urban microenvironment and contribute in biodiversity conservation and diversification and thereby improve the quality of life and provision of natural resources.
\end{abstract}

Keywords: Biodiversity; Urban microenvironment; Natural resources

\section{Introduction}

\section{Problems of the Urban Environment}

In the last thousand years although there has been changes in global climate when there was a medieval warm period followed by a little ice age, but the way temperatures have escalated ever since industrial revolution till present clearly indicates the role of increasing urbanization, deforestation, soil erosion, pollution to name a few.
Although sustainable development was clearly defined in 1987 by the Brundtland Commission / World commission on environment and development when Gro Harlem Brundtland, the former Prime Minister of Norway was the Chairperson of the Commission, but countries worldwide faces innumerable problems that development brings in tow. The major problem of urbanization is that it causes microclimate changes as such areas consume enormous amounts of energy. In such a scenario the goal of urban climate design 


\section{International Journal of Paleobiology \& Paleontology}

is to achieve human comfort for a majority of urban dwellers. NASA in 1997 stated the following

"Improve the comfort of the inhabitants outdoors and indoors, as well as improving the possibilities for the house and surrounding outdoor environment to create a comfortable climate with a minimal energy use ... and to reduce the energy demand of the buildings for heating in winter and for cooling in summer [1]."

\section{Conceptual Framework}

According to Rene A. F. Reaumur (1730) the mean daily air temperatures for 91 days during the months of April, May and June in his locality and found the sum to be a nearly constant value for the development of any plant from year to year. This summation of temperatures, published in 1735 , was later known as Reaumur's thermal constant of phenology [2]. He assumed that his thermometric constant expressed the amount of heat required for a plant to reach a given stage of maturity. This idea gave rise to heat unit system of today. The total amount of heat required, between the lower and upper thresholds, for an organism to develop from one point to another in its life cycle is calculated in units called degree-days $\left({ }^{\circ} \mathrm{D}\right)[3,4]$. Sometimes called heat units, degree-days are the accumulated product of time and temperature between the developmental thresholds for each day.

Heating degree day (HDD) is a measurement designed to measure the demand for energy needed to heat a building. HDD is derived from measurements of outside air temperature. The heating requirements for a given building at a specific location are considered to be directly proportional to the number of HDD at that location. A similar measurement, cooling degree day (CDD), reflects the amount of energy used to cool a home or business.

Now if all the energy that a place receives is used for growth of plants, instead of heating up of the buildings, then it would not lead to urban heat island formation, rather it would create micro-environments wherever done and lead to biodiversity conservation and diversification. According to Rudolf M Schuster [5-8], microenvironment is a very small environment in the immediate vicinity of an organism. According to him new microenvironment differs in humidity, light intensity etc. And if each urban area strives to do the above then global warming created by anthropogenic factors could be stalled. The urban areas can be modified by urban planners and designers, through knowledge of the features that affect the urban environment

\section{Objectives}

1. To analyse microenvironment in an urban context

2. Creation of urban micro-environment as an urban response to sustainable development*

3. Biodiversity conservation and diversification in Delhi by creation of urban micro-environment

\section{Significance of the Study}

1. This study focuses on the relevance of optimum utilization of incoming solar radiation in the urban areas.

2. Reduction of artificial energy utilization and increasing heat outputs.

3. Biodiversity conservation, pollution reduction and stability of the ecosystem.

4. Optimum utilization of space and creation of a rural ambience and ideal daily getaways.

\section{Research Questions}

1. What is the need for creation of microenvironment as an urban response to sustainable development?

2. What is the impact of such microenvironment on biodiversity conservation and diversification?

\section{Study Area: Delhi}

At a Delhi Durbar in 1911, King George V announced the shifting of India's capital from Calcutta (now Kolkata) to Delhi. The foundation stone of the city was laid by George V, Emperor of India during the Delhi Durbar of 1911. It was designed by British architects, Sir Edwin Lutyens and Sir Herbert Baker. The new capital was inaugurated on 13 February 1931, by Viceroy and Governor General of India, Lord Irwin. A slow transformation of Delhi took place and the landscape changed from huge expanses of open space converted to dense settlements and road networks and coming up of Government buildings, public institutions etc. Increase in built up area at the cost of green areas and water bodies. The built-up area in the National Capital Region, which includes residential, non- residential, landfill sites, etc., has increased by 34.6 per cent from 1999-2012. This has happened mostly at the expense of green areas and water bodies which have gone down by 22.5 per cent and 5.9 per cent, respectively (Table 1 ).

According to Demographia World Urban Areas (12 th Annual Edition), Delhi is the 3rd largest city of the world followed by Tokyo Yokohama and Jakarta in 2016. Although according to census of India Literacy in 2011 was 86.21 percent, but Delhi was the most polluted city in the world in 2014 according to WHO. 


\section{International Journal of Paleobiology \& Paleontology}

\begin{tabular}{|c|c|c|c|c|c|c|c|}
\hline $\begin{array}{c}\text { Population } \\
\mathbf{2 0 1 1}\end{array}$ & $\begin{array}{c}\text { Population in } \\
\mathbf{2 0 1 6}\end{array}$ & $\begin{array}{c}\text { Density of } \\
\text { population on } \\
\text { (person s/sqkm) } \\
\mathbf{( 2 0 1 1 )}\end{array}$ & $\begin{array}{c}\text { Percent age } \\
\text { of slum } \\
\text { population } \\
\mathbf{( 2 0 1 1 )}\end{array}$ & $\begin{array}{c}\text { Share of Migrants to } \\
\text { total Population on } \\
\mathbf{( 2 0 0 8 )}\end{array}$ & $\begin{array}{c}\text { Total land } \\
\text { area of } \\
\text { Delhi } \\
\mathbf{( 2 0 1 1})\end{array}$ & $\begin{array}{c}\text { Built up } \\
\text { area in } \\
\mathbf{2 0 0 1} \text { in sq } \\
\text { km }\end{array}$ & $\begin{array}{c}\text { Registered } \\
\text { Vehicles in } \\
\text { Delhi 2015 }\end{array}$ \\
\hline $\begin{array}{c}16.8 \text { million } \\
\text { (acc to census } \\
\text { of India) }\end{array}$ & $\begin{array}{c}25.7 \text { million } \\
\text { (acc to Demogra } \\
\text { phia World } \\
\text { Urban Areas). }\end{array}$ & 11320 & 18.74 & 16.4 & 1483 & 702 & $4,30,603$ \\
\hline
\end{tabular}

Table 1: Important Facts of Delhi.

There is an urgent need for protection of environmentally fragile and sensitive areas of Delhi. Attributing the increase in the built-up area to conversion of agricultural, wastelands, green areas, and water bodies, the Draft Revised Regional Plan-2021 concedes that environmentally fragile and sensitive areas such as the Yamuna riverbed/ wetland, ridge areas, forest areas are being subjected to development activities adversely affecting the land use and eco-system of the area.

\section{Data Base and Methodology}

BSES Rajdhani Power Limited, which is a joint venture of Reliance Infrastructure Ltd. \& Govt. of NCT of Delhi, provides electricity bills to its customers every two months and this data has been used to analyse the change in the micro-environment from 2009 to2017. Besides this, data was also obtained from Census of India, WHO, Demographia World Urban Areas, IMD etc. In this study both quantitative as well as qualitative methods have been used to analyse the problem and conclusion discerned.

\section{Discussion and Results}

India is fortunate to have some of the oldest meteorological observatories of the world. The British East India Company established several such stations at Calcutta in 1785 and Madras in 1796. The Asiatic Society of Bengal founded in 1784 at Calcutta, and in 1804 at Bombay, promoted scientific studies in meteorology in India. India Meteorological Department was established in 1875 in Calcutta, then shifted to Simla in 1905, then to Pune in 1928 and finally to Delhi in 1944. Temperature records for Delhi exist for a period of a little over 100 years. From a cursory view of Tables 2-4 it is clear that ever recorded maximum and minimum temperature and maximum rainfall in Palam, Delhi occurred from 1961 onwards for all months. This indicates the propensity for climate variation from then onwards which also coincides with the fast changing urban landscape of Delhi as a result of in-migration leading to population increase and associated problems. The technological advancements too played its role in escalating the rate of urbanization.

\begin{tabular}{|c|c|c|c|}
\hline Month & Date & Max Temp & Year \\
\hline Jan & 27 & 31 & 2007 \\
\hline Feb & 26 & 35.7 & 2006 \\
\hline March & 27 & 41.3 & 2010 \\
\hline April & 25 & 45.3 & 1970 \\
\hline May & 26 & 48.4 & 1998 \\
\hline June & 8 & 47.6 & 1995 \\
\hline July & 5 & 45.7 & 1987 \\
\hline Aug & 12 & 43.2 & 1987 \\
\hline Sept & 26 & 40.8 & 1987 \\
\hline Oct & 2 & 39.6 & 1961 \\
\hline Nov & 4 & 36.4 & 2001 \\
\hline Dec & 12 & 30 & 1968 \\
\hline
\end{tabular}

Table 2: Ever Recorded Maximum Temperature, upto 2010 at Palam, New Delhi.

\begin{tabular}{|c|c|c|c|}
\hline Month & Date & Min Temp & Year \\
\hline Jan & 11 & -2.2 & 1967 \\
\hline Feb & 6 & -1.6 & 1974 \\
\hline March & 1 & 3.4 & 1972 \\
\hline April & 6 & 8.6 & 1967 \\
\hline May & 2 & 14.6 & 1966 \\
\hline June & 6 & 19.8 & 1970 \\
\hline July & 7 & 17.8 & 1964 \\
\hline Aug & 30 & 20.2 & 1968 \\
\hline Sept & 23 & 13.6 & 1972 \\
\hline Oct & 30 & 9.9 & 1964 \\
\hline Nov & 30 & 2.1 & 1966 \\
\hline Dec & 30 & -1.3 & 1973 \\
\hline
\end{tabular}

Table 3: Ever Recorded Minimum Temperature, upto 2010 at Palam, New Delhi. 


\section{International Journal of Paleobiology \& Paleontology}

\begin{tabular}{|c|c|c|c|}
\hline Month & Date & Rainfall mm & Year \\
\hline Jan & 9 & 52.2 & 1995 \\
\hline Feb & 20 & 47.6 & 1979 \\
\hline March & 2 & 30.8 & 1982 \\
\hline April & 16 & 117.8 & 1983 \\
\hline May & 29 & 77.2 & 2002 \\
\hline June & 30 & 215.6 & 1981 \\
\hline July & 9 & 265.8 & 1972 \\
\hline Aug & 6 & 183.6 & 1967 \\
\hline Sept & 16 & 190.2 & 1963 \\
\hline Oct & 3 & 52 & 2004 \\
\hline Nov & 27 & 75.4 & 1972 \\
\hline Dec & 3 & 33.7 & 1987 \\
\hline
\end{tabular}

Table 4: Ever Recorded Heaviest Rainfall, upto 2010 at Palam, New Delhi.

The study area is located in a densely populated area of south Delhi on the bank of river Yamuna. The consumption chart of electricity from 2009 onwards shows a rapid downfall with increasing changes done to protect the area being heated up in summers and the reverse in winter. By and by the dependence on electrical gadgets for temperature regulation was reduced which led to decrease in electricity consumption and the benefits of going green poured in subsequently (Table 5).

\begin{tabular}{|c|c|c|}
\hline 2009, 2010 \& 2011 & Units & Rupees \\
\hline Nov 2009-Jan 2010 & 756 & 2655 \\
\hline Jan -Feb 2010 & 497 & 1700 \\
\hline Feb -May2010 & 903 & 3050 \\
\hline May-July 2010 & 1511 & 6260 \\
\hline July-Sept, 2010 & 1265 & 5129 \\
\hline Sept-Nov 2010 & 709 & 2450 \\
\hline Nov 2010 - Jan 2011 & 326 & 642 \\
\hline Jan-Feb 2011 & 344 & 1076 \\
\hline Feb-April 2011 & 550 & 1630 \\
\hline April-June 2011 & 1459 & 5920 \\
\hline June-Aug 2011 & 1385 & 5790 \\
\hline Aug-Oct 2011 & 1833 & 9280 \\
\hline Oct-Dec 2011 & 416 & 1050 \\
\hline
\end{tabular}

\begin{tabular}{|c|c|c|}
\hline 2011-2013 & Units & Rupees \\
\hline Dec 2011-Feb 2012 & 481 & 1930 \\
\hline Feb-April 2012 & 601 & 2420 \\
\hline April- June 2012 & 1770 & 9770 \\
\hline June-Aug 2012 & 1990 & 12610 \\
\hline Aug-Oct 2012 & 1172 & 7310 \\
\hline Oct-Dec 2012 & 360 & 1220 \\
\hline Dec 2012-Feb 2013 & 346 & 1290 \\
\hline Feb-March 2013 & 224 & 890 \\
\hline March-April 2013 & 350 & 2980 \\
\hline
\end{tabular}

\begin{tabular}{|c|c|c|}
\hline April-May 2013 & 432 & 2560 \\
\hline May-June 2013 & 1234 & 8590 \\
\hline June-July 2013 & 944 & 6660 \\
\hline July-Aug 2013 & 644 & 4140 \\
\hline Aug-Sept 2013 & 905 & 6162 \\
\hline
\end{tabular}

\begin{tabular}{|c|c|c|}
\hline 2015 - 2016 & Units & Rupees \\
\hline Jan-Feb & 98 & 440 \\
\hline Feb-March & 130 & 450 \\
\hline March-April & 204 & 500 \\
\hline April-May & 213 & 680 \\
\hline May-June & 934 & 6740 \\
\hline June-July & & \\
\hline July-Aug & 541 & 3760 \\
\hline Aug-Sept & 812 & 6120 \\
\hline Sept-Oct & 465 & 3100 \\
\hline Oct-Nov & 185 & 640 \\
\hline Nov-Dec & 94 & 370 \\
\hline Dec-Jan 2016 & 155 & 540 \\
\hline
\end{tabular}

Table 5: Electricity consumption at study area.

The changes done were as follows (Figures 1-7):-

1. Painting of glass of windows and ventilators (colored from inside and white from out for maximum reflection).

2. Each balcony/window protected with slanting tin shade to reduce sunlight penetration and increase its beauty too (Pots were hung with plants which reduced air pollution).

3. Minimum furniture for better air circulation and minimum use of mattresses and cushions to reduce heat absorption.

4. A variety of plants were either bought or brought and placed on the terrace which further helped in reducing heat penetration substantially.

5. The terrace was given an extra protective layer to reduce heat penetration and slanting open cottages were made which served to protect the plants from summer heat and absence of heat in winter.

6. The plants were kept in clusters to reduce the rate of evaporation and the weaker/smaller ones were well shaded.

The benefits incurred were as follows:-

1. Reduction in insolation penetration

2. Reduced pollution levels

3. Reduction in electricity consumption

4. Biodiversity conservation and diversification

5. Herbal garden

6. Production of vegetables and flowers and herbs

7. Aesthetic value 


\section{International Journal of Paleobiology \& Paleontology}

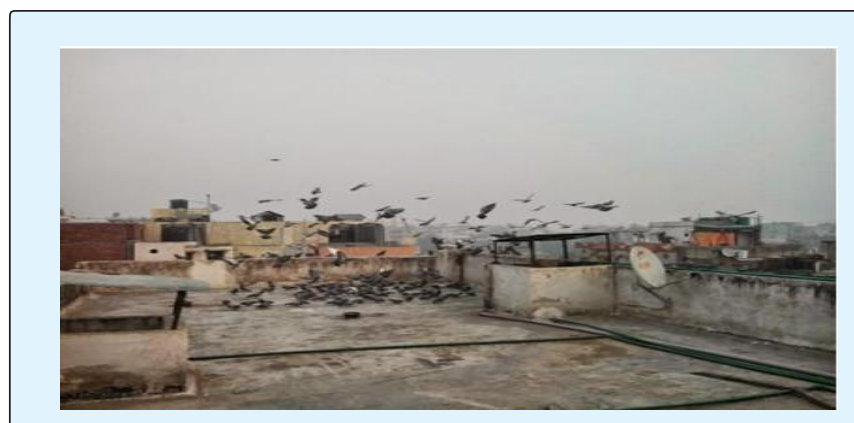

Figure 1: Study area terrace in 2009.

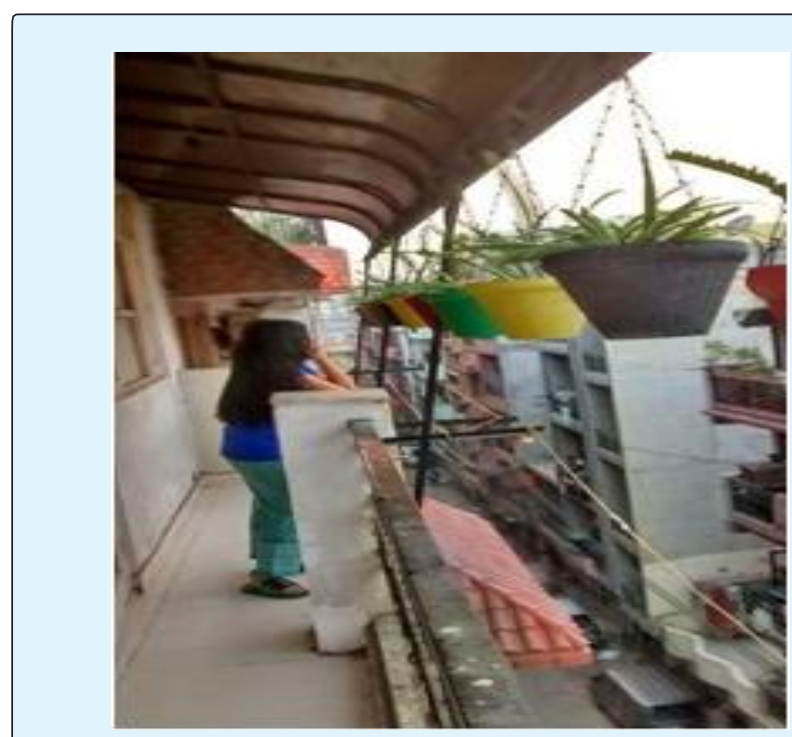

Figure 2: Balcony covered windows glass painted, and pots to reduce pollution hung.

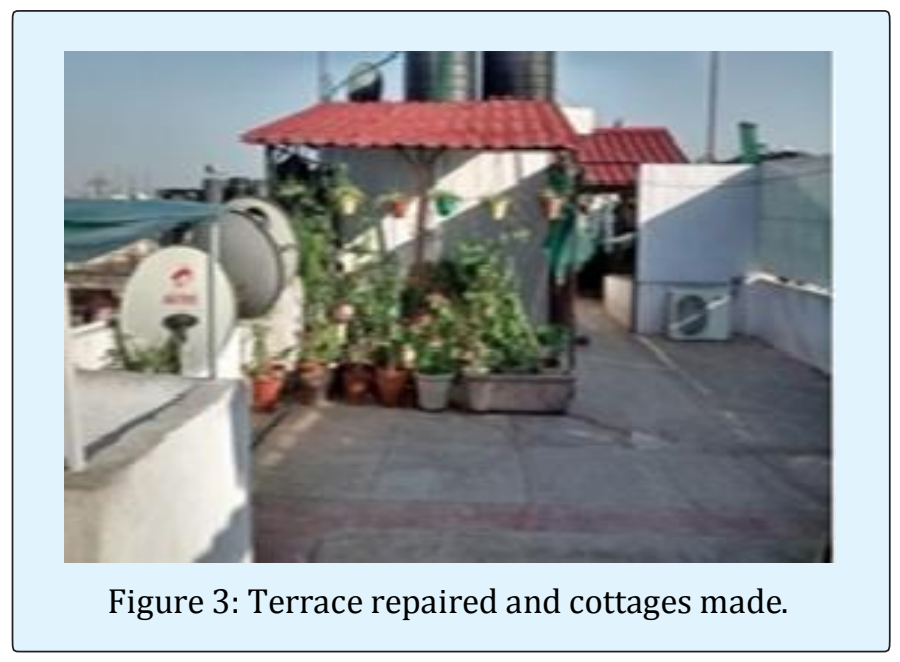

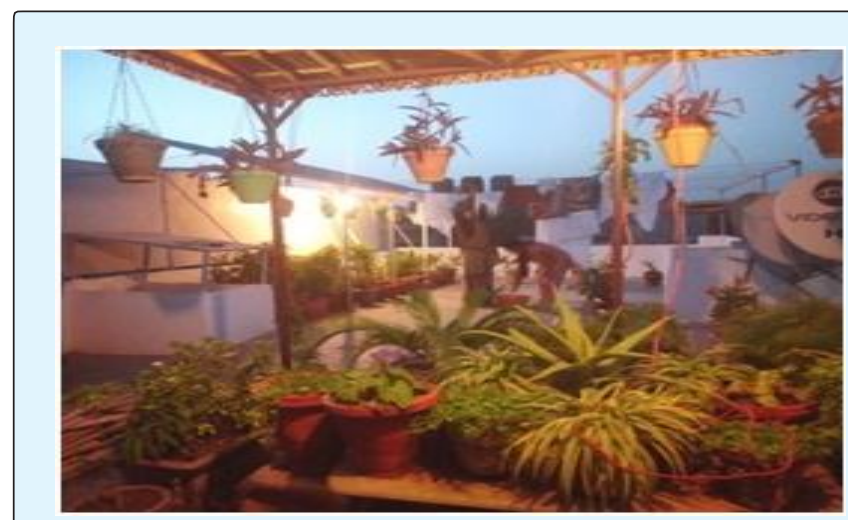

Figure 4: Cottages for plants on the terrace after terrace repaired.

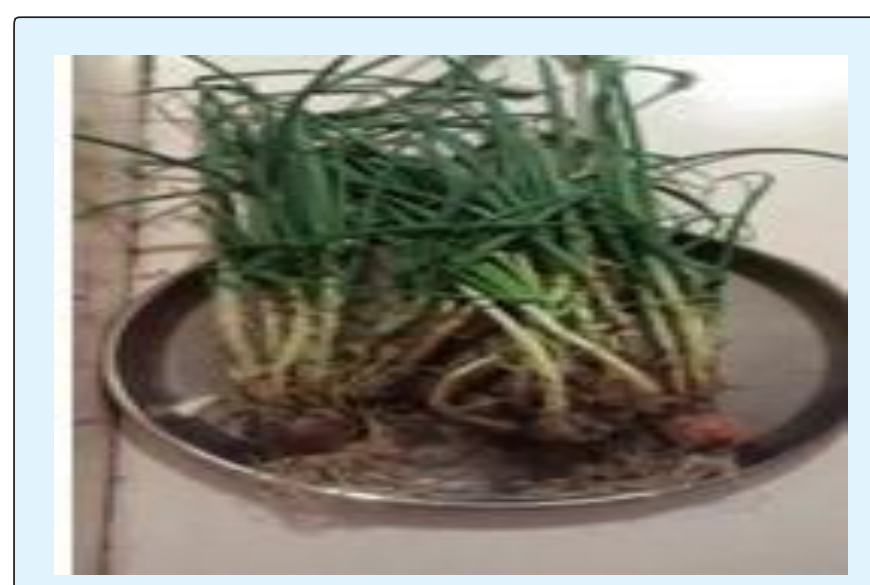

Figure 5: Vegetables ready.

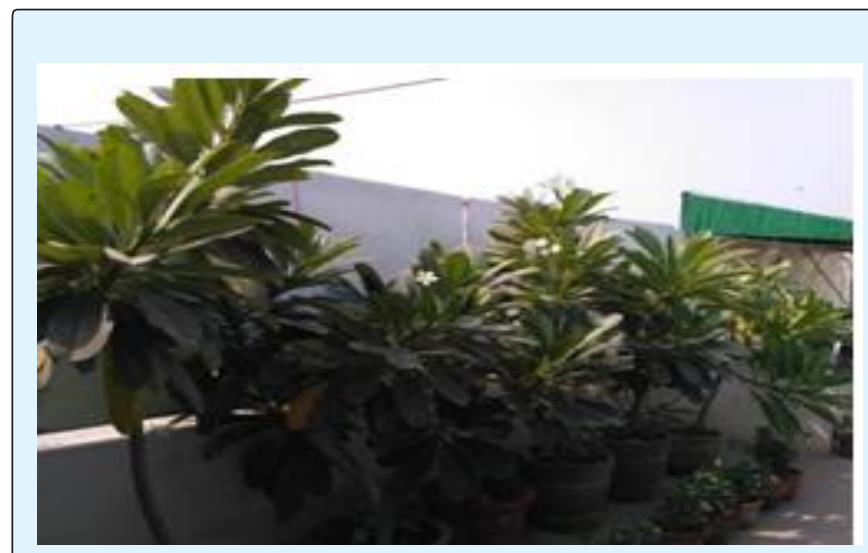

Figure 6: Trees giving ample shade and ready to be transplanted, 2016. 


\section{International Journal of Paleobiology \& Paleontology}

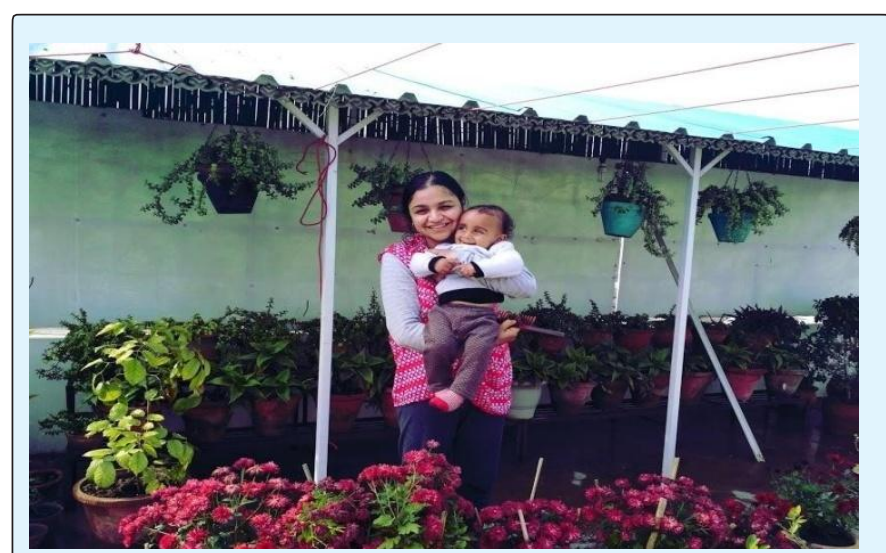

Figure 7: Garden ready 2016.

From an indepth study of the study area it was found, that it is imperative to analyse microenvironment especially in urban areas wherein people live in pathetic condition due to high densities, lack of cross ventilation, minimum green cover leading to polluted environment, spike in home temperatures in summers and vice versa in winters etc. On analyzing the microenvironment, the next step was to envisage ideas to minimize such effects, so that conditions could be made tolerable and would be the optimum response too. This is very significant as it is the ardent desire to artificially create an environment more comfortable and fast, but definitely which is not sustainable as is evident from the above analysis for the electricity consumption escalated in response to this endeavour. In such a scenario, when biodiversity conservation becomes the forte then diversification follows and benefits accrued is multifarious undoubtedly and to begin with electricity consumption fell drastically, followed by reduction in pollution levels and increase in green cover and aesthetic value, leading to biodiversity conservation and diversification by creation of an urban microenvironment.

\section{- Biodiversity conservation and diversification}

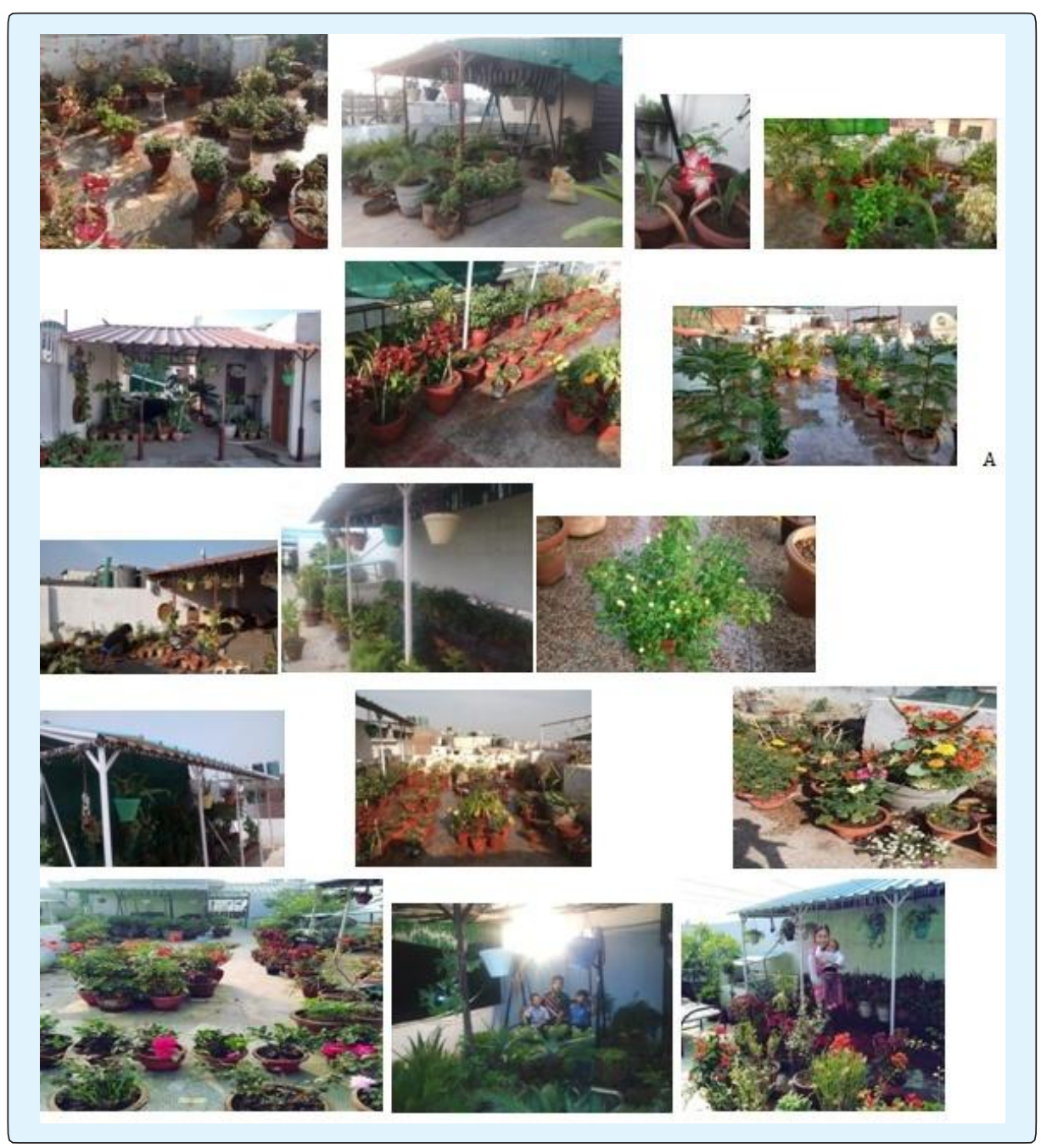

Tahir M. Biodiversity Conservation and Diversification by Creation of Urban MicroEnvironment: A Case Study of Delhi. Int J Paleobiol \& Paleontol 2018, 1(1): 000102. 


\section{International Journal of Paleobiology \& Paleontology}

\section{References}

1. Karl EC, John MQ, Robert JS (2003) Home-Buyers, Housing, and the Macroeconomy. In: Richards A, et al. (eds), Asset Prices and Monetary Policy, Reserve Bank of Australia, pp: 149-188.

2. Jarosík V, Honek A, Magarey RD, Skuhrovec J (2011) Developmental database for phenology models: Related insect and mite species have similar thermal requirements. Journal of Economic Entomology 104(6): 1870-1876.

3. McMaster GS, Wilhelm WW (1997) Growing degreedays: One equation, two interpretations. Agric Forest Meteorol. 87(4): 291-300.
4. Russelle MP, Wilhelm WW, Olson RA, Power JF (1984) Growth analysis based on degree days. Crop Sci. 24(1): 28-32.

5. Schuster RM (1992) The Hepaticae and Anthocerotae of North America, Vol. V, pp. xvii+854,(1992), Vol. VI, pp. xvii+937,(1992), Field Museum of Natural History, Chicago.

6. Gilmore EC, Rogers JS (1958) Heat units as a method of measuring maturity in corn. Agron J 50(10): 611615.

7. http://www.urban-climate-energy.com

8. https://www.nasa.gov/audience/formedia/archives/ MP_Archive_97.html

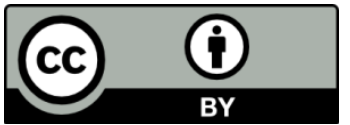

